
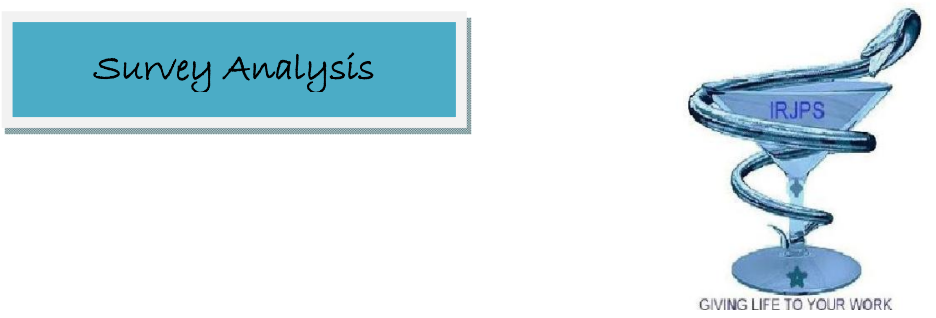

\title{
DETERMINING THE RESEARCH NEEDS AS PERCEIVED BY THE MEDICAL STUDENTS OF THE JORDAN UNIVERSITY OF SCIENCE AND TECHNOLOGY
}

\author{
Ahed Jumah Alkhatib ${ }^{1}$, Zouhair Amarin ${ }^{2}$ \\ ${ }^{1}$ Department of Legal medicine, Toxicology of Forensic Science and Toxicology, Faculty of Medicine, Jordan \\ University of Science and Technology, Jordan. \\ ${ }^{2}$ Department of Obstetrics and Gynecology, Faculty of Medicine, Jordan University of Science and \\ Technology, Jordan.
}

Submitted on: 08.08.16;

Revised on: 17.08.16;

Accepted on: 25.08 .16

\begin{abstract}
Including medical students in research has positive outcome in medical career and leads to build scientific personality of students to cope with fast changes in their field. The present study was conducted to determine the research needs of medical students as perceived by them. The methodology involved making a team of medical students who showed the interest of joining research. Regular meetings to set up the strategy of research process were conducted. A special group on face book was created to have direct contact with group members and to discuss on line any issue or inquiry. The research group sets up the study questionnaire and validates it through conducting a pilot study. The questionnaire included various parts: demographic part, perception part to evaluate how the students believe about the research in terms of its importance and barriers and the research needs part. Study findings showed that 682 medical students participated in the study. Male students were more likely to participate than female students $(53.3 \%-44.7 \%)$. The perception of medical students for joining research was positive for the following variables: joining research increases scientific knowledge and expands thinking horizon, joining research increases development of critical and analytical thinking. Students expressed less positive perception for: A successful physician is an experienced researcher and Medical school curriculum as a prerequisite for graduation. Most of students did not agree with: joining research consumes time on the expense of curricular studies. According to students, research needs included access to facilities, funding, lack of research supervisors and lack of good support from laboratory staff. Students expressed high interest in clinical research (81.4\%). Clinical research preferences were more for medical research. About 36\% of students expressed their thought to have adequate laboratory skills to experience research, about $77 \%$ of students believed that methodology steps have to be included on their curriculum. About $96 \%$ of students expressed their interest and readiness to participate in research. Finally, the data of our study determined predictors of perceptions and research needs of medical students for research. Taken together, we concluded that there is a high interest and readiness of our medical students to participate in research and they are aware of research impacts on the future of their career. It is recommended that decision makers at Jordan University of Science and Technology to take proper measures and actions to offer the chances to include medical students in research in terms of including proper research courses and establishing student research laboratories.
\end{abstract}

KEYWORDS: Medical students, Student's research, Perception, Research needs.

Corresponding author: Ahed J Alkhatib

E-mail: ajalkhatib@just.edu.jo

Mobile no: 00962795905145

Indian Research Journal of Pharmacy and Science; 10(2016) 751-762 Journal Home Page: https://www.irjps.in 


\section{INTRODUCTION}

It has been recognized on the international level that medical education has a social impact due to its effects on the quality of health care services provided to the public ${ }^{1-5}$.

According to $\mathrm{Karle}^{6}$, it has been estimated by the World Federation for Medical Education that there were about 2000 medical schools in the international level in 2006. These schools were shown to look similar in broad terms, but variations in their curricula and training types have been observed.

According to Institute for International Medical Education $^{7}$, it has been recognized that joining activities of scientific research is one of strategies with good potential to enhance the achievement of student's medical education. Furthermore, it has also been shown that optimal performance in daily clinical practice requires a wide range of skills, and accordingly, doctors with scientific training during their medical education usually express better abilities regarding making decisions through using information collected from different sources.

Several studies have targeted the relationship between the engagement of research activities by medical students and medical education and it has been found that there was a positive impact on the motivation of medical students ${ }^{8,9}$.

In another study, Dini et al ${ }^{10}$ showed that doctors with previous experience in scientific programs during their academic years are more likely to make more accurate diagnoses and better professional decisions.

\section{METHODS AND SUBJECTS:}

The present study adopted a cross-sectional study design to collect data from medical students at Faculty of Medicine-Jordan University of Science and Technology. A group of interested medical students was chosen and a series of meetings were conducted with research supervisors. A questionnaire was constructed to include three parts: demographic part concerning with certain variables such as age, gender, etc., the second part was concerning with the student's perception for student's research and the third part was about research needs as reported by students. Second and third parts based on fifth Likert Scale. After the questionnaire had been completed, it was distributed to 20 students to check for the time required for its filling, how much questions are understood and clear, and to give a chance for any comment. Preliminary results indicated that about 5 minutes were required to fill the questionnaire as well as minor changes in three questions to be more understood. Proper changes to the questionnaire were made. The questionnaire was then distributed by emails to medical students. Returned questionnaires were entered to SPSS version 20 for data analysis. Data were presented as frequencies and percentages. The relationships between variables were tested using Chi-Square. Significance was considered at alpha level $\leq 0.05$.

\section{General characteristics of medical students}

As shown in table 1, 682 medical students participated in the present study. The mean of age is $21.18 \pm 1.88$ years. About $53 \%$ of students were males; most of the students were in the academic years from $2^{\text {nd }}$ to $4^{\text {th }}$, about $54 \%$ of students were from Jordan, followed by Malaysian students (16.9\%) and students from Gulf countries (16.6\%), while the remaining students were from Palestine (7.2\%), Syria (1\%) and others (4.5\%). About $60 \%$ of students completed their secondary stage at public secondary schools. The origin of secondary certificate was from Jordan for the majority of students (about 47\%) followed by Gulf certificate (18.3\%), and Malaysian (16.7\%). Medical students reported having GPA in the range 60-69 out of 100 by about $12 \%$, while the remaining student had got higher GPA. The majority of students (about 64\%) reported that their parents had bachelor degree. About $87 \%$ of students were not regular smokers, and about $52 \%$ of students use prescribed eye-glasses. About $44 \%$ of medical students reported being involved in extra-curricular activities. 
Table 1: General characteristics of medical students

\begin{tabular}{|c|c|}
\hline Variables & \\
\hline Age $(M \pm S D)$ years & $21.12 \pm 1.88$ \\
\hline Sex: $(\mathbf{N}, \%)$ & \\
\hline Males & $377(53.3)$ \\
\hline Females & $305(44.7)$ \\
\hline Academic year (N, \%) & \\
\hline $1^{\text {st }}$ & $91(13.3)$ \\
\hline $2^{\text {nd }}$ & $153(22.4)$ \\
\hline $3^{\text {rd }}$ & $161(23.6)$ \\
\hline $4^{\text {th }}$ & $156(22.9)$ \\
\hline $5^{\text {th }}$ & $79(11.6)$ \\
\hline $6^{\text {th }}$ & $42(6.2)$ \\
\hline Area of residence $(\mathrm{N}, \%)$ & \\
\hline -Jordan & $367(53.8)$ \\
\hline - Palestine & $49(7.2)$ \\
\hline - Syria & $7(1)$ \\
\hline - Gulf & $113(16.6)$ \\
\hline - Malaysia & $115(16.9)$ \\
\hline - Others & $31(4.5)$ \\
\hline Type of secondary school (N, \%) & \\
\hline - Private & $274(40.2)$ \\
\hline - Public & $408(59.8)$ \\
\hline Secondary school certification $(\mathrm{N}, \%)$ & \\
\hline - Jordan & $322(47.2)$ \\
\hline - International & $40(5.9)$ \\
\hline - Palestine & $24(3.5)$ \\
\hline - Gulf & $125(18.3)$ \\
\hline - Sijil & $114(16.7)$ \\
\hline - Syrian bachlerioate & $5(0.7)$ \\
\hline - Others & $52(7.6)$ \\
\hline University GPA (N, \%) & \\
\hline$-60-69$ & $80(11.7)$ \\
\hline$-70-79$ & $221(32.4)$ \\
\hline$-80-89$ & $156(22.9)$ \\
\hline$-90-100$ & $225(33)$ \\
\hline Father's educational level (N, \%) & \\
\hline - Master/PhD & $96(14.1)$ \\
\hline - Bachelor & $434(63.9)$ \\
\hline - $\quad$ Secondary school & $115(\mid 16.9)$ \\
\hline - $\quad$ Primary school & $37(5.4)$ \\
\hline Mother's educational level (N, \%) & \\
\hline - $\quad$ Master $/ \mathrm{PhD}$ & $96(14.1)$ \\
\hline - Bachelor & $434(63.9)$ \\
\hline - $\quad$ Secondary school & $115(\mid 16.9)$ \\
\hline - $\quad$ Primary school & $37(5.4)$ \\
\hline
\end{tabular}




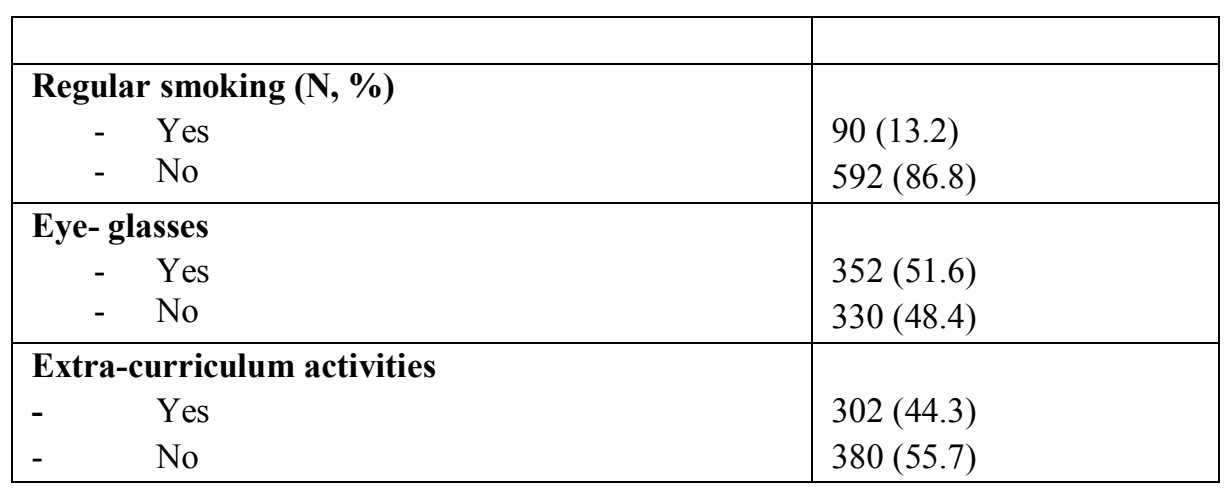

\section{Perception of students for research}

The perception of medical students for research was investigated through various questions using fifth Likert scale as shown in table 2. About $94 \%$ of medical students reported their opinion that being engaged in research will increase their scientific knowledge and expand their thinking horizon. About $94 \%$ of medical students pointed to their agreement that research engagement will also lead to development of critical and analytical thinking.
About half of students reported that research engagement will be on the count of their studying time while about $37 \%$ of students were neutral. When students were asked to report their opinion if "A successful physician is an experienced researcher", about $73 \%$ respond positively, while about $21 \%$ students were neutral. When students were asked for their opinion to include research as prerequisite for graduation, about $67 \%$ of students responded positively, $24 \%$ were neutral and about $8 \%$ did not agree.

Table 2: Perception of students for research

\begin{tabular}{|c|c|c|c|c|c|c|c|c|c|c|}
\hline \multirow[t]{2}{*}{ Perception } & \multicolumn{2}{|c|}{ Strongly agree } & \multicolumn{2}{|c|}{ Agree } & \multicolumn{2}{|c|}{ Neutral } & \multicolumn{2}{|c|}{ disagree } & \multicolumn{2}{|c|}{$\begin{array}{l}\text { Strongly } \\
\text { disagree }\end{array}$} \\
\hline & $\mathbf{N}$ & $\%$ & $\mathbf{N}$ & $\%$ & $\mathbf{N}$ & $\%$ & $\mathbf{N}$ & $\%$ & $\mathbf{N}$ & $\%$ \\
\hline $\begin{array}{l}\text { Scientific knowledge and } \\
\text { expand thinking horizon. }\end{array}$ & 411 & 60.3 & 228 & 33.4 & 41 & 6 & 2 & 0.3 & 0 & 0 \\
\hline $\begin{array}{l}\text { development of critical and } \\
\text { analytical thinking }\end{array}$ & 409 & 60 & 231 & 33.9 & 40 & 5.9 & 2 & 0.3 & 0 & 0 \\
\hline $\begin{array}{l}\text { consumes time on the expense of } \\
\text { curricular studies }\end{array}$ & 87 & 12.8 & 249 & 36.5 & 249 & 36.5 & 97 & 14.2 & 0 & 0 \\
\hline $\begin{array}{l}\text { A successful physician is an } \\
\text { experienced researcher }\end{array}$ & 223 & 32.7 & 274 & 40.2 & 145 & 21.3 & 40 & 5.9 & 0 & 0 \\
\hline $\begin{array}{l}\text { Medical school curriculum as a } \\
\text { prerequisite for graduation. }\end{array}$ & 200 & 29.3 & 261 & 38.3 & 164 & 24 & 57 & 8.4 & 0 & 0 \\
\hline
\end{tabular}

Knowledge of medical students about research requirements

As shown in table 3, about $71 \%$ of medical students reported their knowledge of what is known
"Evidence -based medicine", about 29\% of students know about "'Open Access to Research' which enables you to view full scientific papers for free", about $23 \%$ of students have heard about "'Student- 
Conducted Research' in our university", about 29\% of students heard about 'OPen Access to Research' which enables you to view full scientific papers for free". In general, medical students reported that they depend on articles and medical journals since more than two thirds of them refer to such readings in the last year at various ranges, but predominant range was $1-5$ articles as reported by about $32 \%$ of them. About $28 \%$ of students reported that they had the opportunity or been invited to take part in any research. Finally, about 14\% reported their actual participation in a research.

Table 3: Knowledge of medical students about research requirements

\begin{tabular}{|c|c|}
\hline Variables & \\
\hline $\begin{array}{l}\text { Have you ever heard of 'Evidence-Based Medicine'? (N, \%) } \\
-\quad \text { yes } \\
-\quad \text { no }\end{array}$ & $\begin{array}{l}486(71.3) \\
196(28.7)\end{array}$ \\
\hline $\begin{array}{l}\text { Have you ever heard of 'Open Access to Research' which enables you to view } \\
\text { full scientific papers for free? (N, \%) } \\
-\quad \text { yes } \\
-\quad \text { no }\end{array}$ & $\begin{array}{l}195(28.6) \\
487(71.4)\end{array}$ \\
\hline 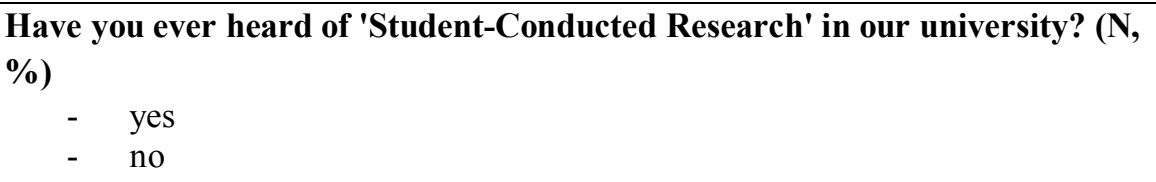 & $\begin{array}{l}155(22.7) \\
527(77.3)\end{array}$ \\
\hline $\begin{array}{l}\text { In the last year, how many articles or medical journals have you read? (N, } \\
\text { \%) } \\
\begin{array}{ll}- & \text { none } \\
- & 1-5 \\
- & 6-10 \\
- & >10\end{array}\end{array}$ & $\begin{array}{l}217(31.8) \\
318(46.6) \\
67(9.8) \\
79(11.6)\end{array}$ \\
\hline $\begin{array}{l}\text { Have you ever had the opportunity or been invited to take part in any } \\
\text { research? }(\mathbf{N}, \%) \\
-\quad \text { yes } \\
-\quad \text { No }\end{array}$ & $\begin{array}{l}188(27.6) \\
494(72.4)\end{array}$ \\
\hline $\begin{array}{l}\text { Have you ever 'participated' in a research? } \\
-\quad \text { yes } \\
-\quad \text { no }\end{array}$ & $\begin{array}{l}97(14.2) \\
585(85.8)\end{array}$ \\
\hline
\end{tabular}

\section{Research needs as perceived by medical students}

As shown in table 4, medical students think that facilities accessibility is a problem that forms a barrier for conducting research; this opinion is agreed by about $71 \%$ of students, while about $26 \%$ were neutral. About $4 \%$ of medical students did not agree. About $75 \%$ of medical students expressed their ideas that funding is also a barrier to conduct research in their university, about $19 \%$ were neutral. About $74 \%$ of medical students reported that lack of research supervisors and guidance is considered as another problem that faces the idea of conducting student research, about $20 \%$ of students were neutral. About $72 \%$ of medical students reported that lacking of good support from the laboratory staff presents a barrier for conducting research, while about $23 \%$ of medical students were neutral. 
Table 4: Research needs as perceived by medical students

\begin{tabular}{|c|c|c|c|c|c|c|c|c|c|c|}
\hline \multirow[t]{2}{*}{ Research need } & \multicolumn{2}{|c|}{ Strongly agree } & \multicolumn{2}{|c|}{ Agree } & \multicolumn{2}{|c|}{ Neutral } & \multicolumn{2}{|c|}{ disagree } & \multicolumn{2}{|c|}{$\begin{array}{l}\text { Strongly } \\
\text { disagree }\end{array}$} \\
\hline & $\mathbf{N}$ & $\%$ & $\mathbf{N}$ & $\%$ & $\mathbf{N}$ & $\%$ & $\mathbf{N}$ & $\%$ & $\mathbf{N}$ & $\%$ \\
\hline $\begin{array}{l}\text { Access to facilities presents a } \\
\text { problem to conduct a research } \\
\text { in our university }\end{array}$ & 176 & 25.8 & 303 & 44.4 & 175 & 25.7 & 28 & 4.1 & 0 & 0 \\
\hline $\begin{array}{l}\text { Funding } \text { (finding } \text { financial } \\
\text { support) presents a problem to } \\
\text { conduct a research in our } \\
\text { university }\end{array}$ & 205 & 30.1 & 303 & 44.4 & 126 & 18.5 & 48 & 7 & 0 & 0 \\
\hline $\begin{array}{l}\text { Lack of research supervisors } \\
\text { and guidance presents a } \\
\text { problem to conduct research in } \\
\text { our university }\end{array}$ & 246 & 36.1 & 261 & 38.3 & 133 & 19.5 & 42 & 6.2 & 0 & 0 \\
\hline $\begin{array}{l}\text { Lack of good support from the } \\
\text { laboratory staff presents a } \\
\text { barrier for conducting a } \\
\text { research in our university }\end{array}$ & 249 & 36.5 & 239 & 35 & 156 & 22.9 & 38 & 5.6 & 0 & 0 \\
\hline
\end{tabular}

\section{Research attitudes of medical students}

As shown in table 5, about $82 \%$ of medical students showed their interest to participate in clinical research, while about $19 \%$ showed interest in conducting research in basic sciences. Basic sciences research ranked firstly in pathology (14.8\%), followed by physiology (12.9\%). For those who prefer clinical research, medical researches $(46.3 \%)$ were slightly preferred more than surgical researches (42.2\%). About $13 \%$ of medical students reported that they heard about an opportunity for undergraduate students in their university to publish their research. About $36 \%$ of students think that they have adequate laboratory and statistical skills to qualify them for participation in research. About 77\% of students expressed their opinions to focus more on research methodology in their curriculum, followed by publication skills (12.6\%) and literature review $(10.4 \%)$. About $31 \%$ of medical students think about long term career in research and about $95 \%$ of them are currently interested and ready to participate in research. 
Table 5: Research attitudes of medical students

\begin{tabular}{|c|c|}
\hline Variables & \\
\hline $\begin{array}{l}\text { Do you prefer to take place in a basic sciences or clinical research? } \\
\text { - } \quad \text { Basic Sciences Research } \\
\text { - } \quad \text { Clinical Research }\end{array}$ & $\begin{array}{l}127(18.6) \\
555(81.4)\end{array}$ \\
\hline $\begin{array}{cl}\text { If you prefer basic sciences research, which field do you prefer? } \\
-\quad \text { Anatomy } \\
-\quad \text { Pathology } \\
-\quad \text { Physiology } \\
-\quad \text { Biochemistry \& Genetics } \\
-\quad \text { Pharmacology }\end{array}$ & $\begin{array}{l}48(7) \\
101(14.8) \\
88(12.9) \\
40(5.9) \\
25(3.7)\end{array}$ \\
\hline $\begin{array}{l}\text { If you prefer clinical researches, what do you prefer? } \\
\text { - Medical Researches } \\
\text { - Surgical Researches }\end{array}$ & $\begin{array}{l}316(46.3) \\
288(42.2)\end{array}$ \\
\hline $\begin{array}{l}\text { Have you ever heard about an opportunity for undergraduate students in } \\
\text { our university to publish their research? } \\
- \text { yes } \\
- \text { no } \\
\end{array}$ & $\begin{array}{l}88(12.9) \\
594(87.1)\end{array}$ \\
\hline $\begin{array}{l}\text { Do you think you have the adequate laboratory and statistical skills which } \\
\text { enable you to conduct or participate in a research? } \\
- \text { yes } \\
- \text { no }\end{array}$ & $\begin{array}{l}243(35.6) \\
439(64.4)\end{array}$ \\
\hline $\begin{array}{l}\text { Which of the following aspects of research do you feel there should be more } \\
\text { emphasis on as part of our curriculum? } \\
\text { - Methodology [Steps to perform a research] } \\
\text { - Literature Review [Obtaining previous studies done on the same subject] } \\
\text { - Undergraduate Publication [How to publish a paper when you are still a student }\end{array}$ & $\begin{array}{l}525(77) \\
71(10.4) \\
86(12.6)\end{array}$ \\
\hline $\begin{array}{l}\text { Have you ever considered a long-term career in research? } \\
\begin{array}{l}-\quad \text { yes } \\
-\quad \text { no }\end{array}\end{array}$ & $\begin{array}{l}208(30.5) \\
474(69.5)\end{array}$ \\
\hline $\begin{array}{l}\text { I am currently interested and ready to participate in a research } \\
\text { - Interested and ready } \\
\text { - Interested but not ready } \\
\text { - Not interested nor ready }\end{array}$ & $\begin{array}{l}651(95.5) \\
0(0 \%) \\
31(4.5)\end{array}$ \\
\hline
\end{tabular}

The relationship between research perception variables and demographic variables

As shown in table 6, the perception that research engagement increases scientific knowledge and expand thinking horizon is associated significantly with "secondary school" $(p=0.018)$, "Secondary school certification" $(\mathrm{p}=0.009)$, "father education level" $(p=0.006)$, "mother education level" $(p=$ $0.006)$ and "extracurricular activities" $(p=0.000)$. The perception that research engagement increases lead to development of critical and analytical thinking is associated significantly with "extracurricular activities" $(p=0.026)$. The perception that research engagement consumes time on the expense of curricular studies did not correlate with any variable significantly. The perception that a successful physician is an experienced researcher is associated significantly with the following variables: "sex" $(p=0.014)$, "academic year" $(p=0.000)$, "area of residence" ( $p=0.007)$, and "secondary school certification" (0.009). The perception that medical 
school curriculum as a prerequisite for graduation is correlated significantly with the following variables "sex" $(p=0.008)$, "secondary school" $(p=0.02)$ and "secondary school certification" $(p=0.015)$. Knowing evidence-based medicine was shown to be associated significantly with "academic year" $(\mathrm{p}=$ $0.000)$, "area of residence" $(\mathrm{p}=0.005)$ and "secondary school certification" $(p=0.003)$. The data of the present study revealed that open access to research was correlated positively with the following variables: "academic year" $(p=0.045)$, "area of residence" (0.012), "secondary school" $(p=0.031)$, "secondary school certification" $(p=0.001)$ and "extracurricular activities" $(\mathrm{p}=0.012)$. Student- conducted research was associated significantly with "academic year" ( $p=0.024)$, "area of residence" (0.011), "secondary school" $(p=0.012)$ and "extracurricular activities" $(p=0.000)$. Number of read articles was associated with "secondary school" $(\mathrm{p}=0.045)$, "secondary school certification" $(\mathrm{p}=$ $0.021)$ and "extracurricular activities" $(\mathrm{p}=0.000)$. Being invited to participate in any research was associated significantly with "academic year" $(\mathrm{p}=$ $0.003)$ and "extracurricular activities" $(\mathrm{p}=0.000)$. Participation in a research is associated significantly with "academic year" $(\mathrm{p}=0.027)$ and "extracurricular activities" $(p=0.002)$.

Table 6: The relationship between research perception variables and demographic variables

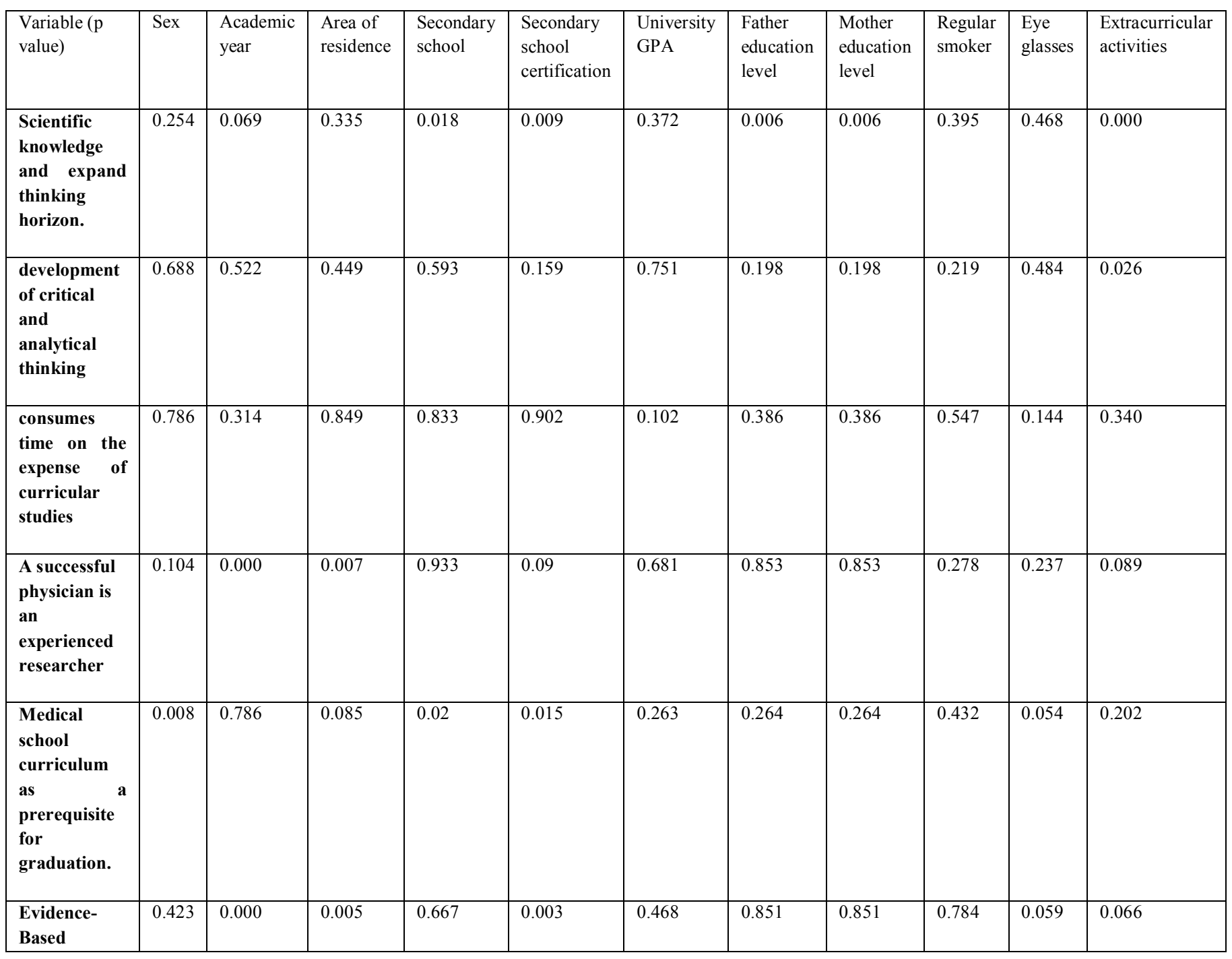




\begin{tabular}{|l|l|l|l|l|l|l|l|l|l|l|l|}
\hline Medicine & & & & & & & & & & & \\
\hline $\begin{array}{l}\text { Open Access } \\
\text { to Research }\end{array}$ & 0.17 & 0.045 & 0.012 & 0.031 & 0.001 & 0.275 & 0.807 & 0.807 & 0.803 & 0.818 & 0.012 \\
\hline $\begin{array}{l}\text { Student- } \\
\text { Conducted } \\
\text { Research }\end{array}$ & 0.119 & 0.024 & 0.011 & 0.577 & 0.012 & 0.818 & 0.687 & 0.687 & 0.570 & 0.465 & 0.000 \\
\hline $\begin{array}{l}\text { how many } \\
\text { articles or } \\
\text { medical } \\
\text { journals }\end{array}$ & 0.441 & 0.081 & 0.687 & 0.045 & 0.021 & 0.313 & 0.303 & 0.303 & 0.815 & 0.847 & 0.000 \\
\hline $\begin{array}{l}\text { been invited } \\
\text { to take part } \\
\text { in any } \\
\text { research }\end{array}$ & 0.864 & 0.003 & 0.179 & 0.294 & 0.20 & 0.549 & 0.097 & 0.097 & 0.223 & 0.306 & 0.000 \\
\hline $\begin{array}{l}\text { Have you } \\
\text { ever } \\
\text { 'participated' } \\
\text { in a } \\
\text { research? }\end{array}$ & 0.455 & 0.027 & 0.676 & 0.658 & 0.81 & 0.578 & 0.818 & 0.818 & 0.809 & 0.598 & 0.002 \\
\hline
\end{tabular}

The relationship between research need variables and demographic variables

As shown in table 7, access to facilities is associated significantly with "sex" $(\mathrm{p}=0.003)$, "secondary school" $(p=0.004)$ and "Secondary school certification" $(p=0.008)$ and "extracurricular activities" $(p=0.032)$. Research funding associated significantly with "sex" $(p=0.015)$, "academic year" $(p=0.008)$, "Area of residence" $(0.038)$, "Secondary school certification" $(p=0.033)$ and "extracurricular activities" ( $p=0.006)$. Lack of supervisors is correlated significantly with "sex" $(p=0.009)$ and "academic year" (0.004). Lack of laboratory staff support is associated significantly with "secondary school" (0.012). Preferring basic sciences or clinical research is associated significantly with"academic year" ( $p=0.000)$ and "father' education and mother' education" $(\mathrm{p}=0.02)$. Basic sciences research is associated significantly with "secondary school" $(\mathrm{p}=$ $0.006)$, "secondary school certification" $(p=0.037)$ and "father's and mother's education" ( $\mathrm{p}=0.016)$. Clinical researches selection is associated significantly with "academic year" $(\mathrm{p}=0.003)$ and regular smoking $(\mathrm{p}=0.022)$.

Table 7: The relationship between research need variables and demographic variables

\begin{tabular}{|l|l|l|l|l|l|l|l|l|l|l|}
\hline $\begin{array}{l}\text { Variable (p } \\
\text { value) }\end{array}$ & Sex & $\begin{array}{l}\text { Academic } \\
\text { year }\end{array}$ & $\begin{array}{l}\text { Area of } \\
\text { residence }\end{array}$ & $\begin{array}{l}\text { Secondary } \\
\text { school }\end{array}$ & $\begin{array}{l}\text { Secondary } \\
\text { school } \\
\text { certification }\end{array}$ & $\begin{array}{l}\text { University } \\
\text { GPA }\end{array}$ & $\begin{array}{l}\text { Father } \\
\text { education } \\
\text { level }\end{array}$ & $\begin{array}{l}\text { Mother } \\
\text { education } \\
\text { level }\end{array}$ & $\begin{array}{l}\text { Regular } \\
\text { smoker }\end{array}$ & $\begin{array}{l}\text { Eye } \\
\text { glasses }\end{array}$ \\
\hline $\begin{array}{l}\text { Access to } \\
\text { facilities }\end{array}$ & 0.003 & 0.071 & 0.220 & 0.004 & 0.008 & 0.811 & 0.604 & 0.604 & 0.487 & 0.161 \\
activities \\
\hline Funding
\end{tabular}




\begin{tabular}{|c|c|c|c|c|c|c|c|c|c|c|c|}
\hline $\begin{array}{l}\text { laboratory } \\
\text { support }\end{array}$ & & & & & & & & & & & \\
\hline $\begin{array}{l}\text { basic } \\
\text { sciences or } \\
\text { clinical } \\
\text { research }\end{array}$ & 0.343 & 0.000 & 0.358 & 0.837 & 0.273 & 0.127 & 0.020 & 0.020 & 0.094 & 0.775 & 0.152 \\
\hline $\begin{array}{l}\text { Basic } \\
\text { sciences } \\
\text { research }\end{array}$ & 0.322 & 0.229 & 0.056 & 0.006 & 0.037 & 0.079 & 0.016 & 0.016 & 0.852 & 0.672 & 0.231 \\
\hline $\begin{array}{l}\text { Clinical } \\
\text { researches }\end{array}$ & 0.234 & 0.003 & 0.554 & 0.477 & 0.853 & 0.664 & 0.245 & 0.245 & 0.022 & 0.181 & 0.807 \\
\hline $\begin{array}{l}\text { Student } \\
\text { research } \\
\text { publishing }\end{array}$ & 0.286 & 0.016 & 0.550 & 0.279 & 0.136 & 0.344 & 0.164 & 0.164 & 0.378 & 0.090 & 0.000 \\
\hline $\begin{array}{l}\text { laboratory } \\
\text { and } \\
\text { statistical } \\
\text { skills }\end{array}$ & 0.018 & 0.001 & $\begin{array}{l}0.109 \\
\end{array}$ & 0.003 & 0.236 & 0.446 & 0.832 & 0.832 & 0.625 & 0.304 & 0.585 \\
\hline $\begin{array}{ll}\text { Aspects } & \text { of } \\
\text { research } & \text { to } \\
\text { be added } & \end{array}$ & 0.696 & 0.808 & 0.662 & 0.367 & 0.327 & 0.018 & 0.762 & 0.762 & 0.625 & 0.061 & 0.782 \\
\hline $\begin{array}{l}\text { long-term } \\
\text { career in } \\
\text { research }\end{array}$ & 0.735 & 0.583 & 0.000 & 0.560 & 0.000 & 0.706 & 0.411 & 0.411 & 0.010 & 0.003 & 0.136 \\
\hline $\begin{array}{l}\text { Readiness } \\
\text { for } \\
\text { participation }\end{array}$ & 0.430 & 0.115 & 0.175 & 0.357 & 0.043 & 0.218 & 0.509 & $\begin{array}{l}0.509 \\
\end{array}$ & 0.114 & 0.462 & 0.034 \\
\hline
\end{tabular}

\section{DISCUSSION}

The present study was conducted in the light of various facts among which is the increasing awareness of engagement of medical students in research activities to improve both their academic and clinical levels in addition to give a chance for interested students in research to experience research at an early stage.

Another important reason beyond conducting this study is that in many developing countries including Jordan, research activity is not a mandatory component of medical education even though such experiences can have a positive impact on the quality of medical education ${ }^{11}$.

The data of our results showed that medical students had positive perceptions for joining research activities to increase scientific knowledge and expand thinking horizon. They also expressed positive perceptions for development of critical and analytical thinking. The previous perceptions indicate clearly that medical students at our university have high interest in research from a theoretical point of view and this is plausibly due to the institutional influence of the university which encourages research activities to hire an advanced position. About $50 \%$ of medical students perceived that research activities consume time on the expense of curricular studies. This perception indicates that medical students were aware of requirements and commitments of research activities. About $73 \%$ of medical students agreed that a successful physician is an experienced researcher. This perception is consistent with previous perceptions. Medical students in general perceived that research activities to be included in medical 
school curriculum as prerequisite for medical education. Taken together, our medical students have positive perceptions for joining research activities, and it is the responsibility of decision making personnel to take proper measures to make joining research by medical students as a new feature of medical education.

Investigating the knowledge of medical students about research requirements indicated good awareness of various components of research including evidence -based medicine and reading medical articles. On the other hand, our medical students were less knowledgeable in "open access to research" and "Student-Conducted Research in our university". The last two variables were expected to be associated with less knowledge since they are both due to conducting research and publishing. Only about $14 \%$ of medical students have already participated in research which reflects a gap in educational programs to include medical students in research.

Research needs have been identified by medical students as: access to facilities, funding and lack of supervisors and good support from laboratory staff. No doubt that the major problem is having large number of students compared with teaching staff from one side and from the other side teaching staff have other clinical activities that take their time on the account of research. Another important point, the teaching staff has to conduct research as requirement for their work and due to have time limitations may think that working with students is time consuming.

\section{REFERENCES}

1. Dancy MH, Beichner RJ. But are they learning? Getting started in classroom evaluation. Cell Biol Educ, 2002, 1 (3):87-94.

2. Ferguson E, James D, Madeley L. Factors associated with success in medical school: systematic review of the literature. BMJ, 2002, 324 (7343):9527.

3. Brotherton SE, Rockey PH, Etzel SI. US graduate medical education, 2003-2004. JAMA, 2004, 292 (9):1032-7.
According to students, they mostly prefer joining clinical research, and about one third of these students believed about their readiness for conducting research, and the majority of medical students believed methodology section to be added in their curriculum. Finally, about $96 \%$ of students expressed their interest and readiness for joining research. Taken together, we have a large group of students who are motivated to join research.

\section{CONCLUSIONS}

The present study showed that medical students at Jordan University of Science and Technology are highly interested in joining research and they are aware of its positive impacts on their future career. Medical student in the present study are more interested in clinical research compared with basic research. It is also concluded that if the high energy stored in students is well employed, we will find a unique way to discover and take care of a new generation of future researcher. Finally, the present study was a simple attempt to present student research and to give them a chance to express their energies, interest and abilities.

\section{ACKNOWLEDGEMENT}

The authors would like to thank the following medical students for their great efforts in carrying out this study : Ahmad Jarrar, Siwar Abu Arqob, Hiba Salhah, Reem Kasim Ali, Zainab Anwar, Marwa Nairat, Omar Shunnar, Mohammad Hariz, Haytham Abdelqader Tariq Kewan.

4. Lempp H, Seale C. The hidden curriculum in undergraduate medical education: qualitative study of medical students' perceptions of teaching. BMJ, 2004, 329 (7469):770-3.

5. Smits PB, Verbeek JH, Nauta MC, ten Cate TJ, Metz JC, van Dijk FJ. Factors predictive of successful learning in postgraduate medical education. Med Educ, 2004, 38 (7):758-66. 
6. Karle H (2006). Global standards and accreditation in medical education: a view from the WFME. Acad Med, 2006, 81 (12):43-8.

7. Core Committee, Institute for International Medical Education. Global minimum essential requirements in medical education. Med Teach, 2002, $24(2): 130-5$.

8. Solomon SS, Tom SC, Pichert J, Wasserman D, Powers AC. Impact of medical student research in the development of physician-scientists. J Investig Med, 2003, 51 (3):149-56.
9. Takahashi O, Ohde S, Jacobs JL, Tokuda Y, Omata F, Fukui T. Residents' experience of scholarly activities is associated with higher satisfaction with residency training. J Gen Intern Med, 2009, 24 (6):716-20.

10. Dini P, Batista N. Graduac, $\mathrm{a}^{\sim} \mathrm{o}$ e, Pra'tica Me'dica: Expectativas e Concepc,ões de Estudantes de Medicina do $1^{\circ}$ ao $6^{\circ}$ ano. Rev Bras Educ Med, 2004, 28 (3):198-203.

11. Neilton A de Oliveira, Maurı'cio R Luz, Roberto M Saraiva, Luiz A Alves. Student views of research training programs in medical schools. Medical Education, 2011 45: 748-755. 